\title{
ДОСЛІДЖЕННЯ ВПЛИВУ ДОПОМІЖНИХ РЕЧОВИН НА ФАРМАКО-ТЕХНОЛОГІЧНІ ВЛАСТИВОСТІ ПОРОШКОВИХ МАС ПРИ РОЗРОБЦІ ТЕХНОЛОГІЇ ТАБЛЕТОК ЕКСТРАКТУ ГРУШАНКИ КРУГЛОЛИСТОЇ
}

\author{
() Н. П. Дарзулі ${ }^{1}$, Т. А. Грошовий${ }^{1}$, К. В. Соколова², О. А. Подплетня ${ }^{2}$
}

ДВНЗ «Тернопільський державний медичний університет імені І. Я. Горбачевського мО3 України» ${ }^{1}$

Д3 «Дніпропетровська медична академія МОЗ України»²

darzulinp@tdmu.edu.ua

\begin{abstract}
Мета роботи. Дослідження впливу допоміжних речовин на фрармако-технологічні властивості порошкових мас для таблетування при розробці таблеток методом прямого пресування на основі сухого екстракту грушанки круглолистої.

Матеріали і методи. Використано сухий екстракт грушанки круглолистої та 27 допоміжних речовин п'яти технологічних груп. Вивчення впливу допоміжних речовин на фармако-технологічні властивості сумішей для таблетування, а саме: кут природного укосу, вільну насипну густину, насипну густину після ущільнення та текучість проводили відповідно до вимог ДФу 2 видання. Процес пресування таблеток екстракту грушанки круглолистої оцінювали за п'ятибальною шкалою.

Результати й обговорення. При створенні таблеток методом прямого пресування вивчено вплив 27 допоміжних речовин (ДР) на фрармако-технологічні показники сумішей для таблетування, що містять екстракт грушанки круглолистої. Дослідження проводили з використаннням математичного планування експерименту - греколатинського кубу 2-го порядку.

Результати дисперсійного аналізу експериментальних даних показали, що найкращу текучість порошкових мас 3 екстрактом грушанки круглолистої забезпечують фруктоза, Vivapur 200, крохмаль картопляний, неуселін US 2 та кальцію стеарат.

Найменше значення кута природнього укосу порошкових мас з екстрактом грушанки круглолистої отримували при використанні фрруктози, крохмалю картопляного, МКЦ 302, неуселіну US 2 і магнію стеарату.

Найбільше значення вільної насипної густини порошкових мас з екстрактом грушанки круглолистої отримували при використанні цукру Compri МЗ натрій карбоксиметилкрохмалю, крохмалю картопляного, кальцію гідрофроссрату безводного, МКЦ бурсту, а насипної густини після ущільнення - цукру Compri M3, крохмалю картопляного, кальцію гідрофросорату безводного, МКЦ бурсту.

Найкращі значення показника індексу Кара отримали при використанні крохмалю картопляного та фрруктози. Найкраще процес пресування таблеток відбувався при використанні таблетози 80, парлітолу 200 SD, лудіпресу, Prosolv SMCC 90, Vivapur 200, VIvapur 14, Prosolv EASYtab SP, Vivapur 102.

Висновки. За допомогою греко-латинського кубу 2-го порядку вивчено вплив 27-ми ДР на фрармако-технологічні властивості порошкових мас (плинність, кут природного укосу, вільну насипну густину, насипну густину після ущільнення) і процес пресування таблеток з екстрактом листя грушанки круглолистої.

Фармако-технологічні показники порошкових мас екстракту грушанки круглолистої з ДР вказують на можливість отримання таблеток методом прямого пресування.
\end{abstract}

Ключові слова: таблетки; фрармако-технологічні показники порошкових мас; рослинні екстракти; грушанка круглолиста; математичне планування експерименту.

Вступ. Хронічна ниркова недостатність є однією 3 найважливіших проблем сучасної нефрології, оскільки є кінцевим результатом прогресуючого перебігу хронічних захворювань нирок. Основною причиною швидкого розвитку ниркової недостатності є часті рецидиви. Анатомічна будова та фрункціональні особливості сечовивідних шляхів часто $€$ причиною хронічних запальних захворювань сечовивідної системи [1].

Причиною гострих та хронічних пієлонесритів $€$ інфрікування патогенними мікроорганізмами, тому основним методом лікування є адекватна антибактеріальна терапія, вважається достатнім курс лікування сучасними видами антибіотиків протягом 10-14

ISSN 2312-0967. Фармацевтичний часопис. 2018. № 2 
днів $[1,2]$. Окрім антибіотиків, широко використовують лікарські препарати на основі рослинної сировини, що підвищують ефективність комплексного лікування та не мають гостро виражених побічних властивостей, можна приймати тривалий термін [3, 4].

Особливо актуально це при лікуванні хронічних захворювань нирок, які вимагають постійного приймання лікарських засобів з метою профілактики рецидивів [1, 3]. Дослідженню лікарської рослинної сировини - листя грушанки круглолистої, присвячено ряд робіт зарубіжних науковців, які встановили широкий спектр фрармакологічної активності лікарської рослини $[5,6]$. В народній медицині застосовують листя і траву грушанки як сечогінний, антисептичний, протизапальний, кровоспинний, жовчогінний, в'яжучий, знеболювальний і ранозагоювальний засоби $[7,8]$. Зі специфрічних особливостей необхідно згадати, що відвар листя грушанки в експерименті показав високу терапевтичну ефективность при експериментальному гломерулонесриті у щурів [9].

Враховуючи особливості фрармацевтичного ринку України рослинних лікарських засобів, які використовують для лікування запальних захворювань сечовидільної системи, доцільна розробка нових лікарських засобів на основі рослинної сировини з вищевказаною фрармакологічною дією [10].
Фармацевтична технологія, біофармація, гомеопатія Pharmaceutical technology, biopharmacy, homeopathy

Мета роботи - вивчення впливу ДР на фрармакотехнологічні властивості порошкових мас для таблетування з метою розробки таблеток із сухим екстрактом грушанки круглолистої методом прямого пресування.

Матеріали і методи. При розробці технології таблеток використовували самостійно отриманий сухий екстракт грушанки круглолистої та допоміжні речовини, які відповідають вимогам Державної фрармакопеї України (ДФУ) і забезпечують виконання всіх фармако-технологічних показників якості таблетованих препаратів [11]. У дослідженнях ми використали 27 сертифрікованих допоміжних речовин вітчизняного та зарубіжного виробництва («ОрісілКалуш» ДП, Harke Pharma GmbH, JRS Pharma, Fuji Chemical Industri Co, Magnesia GmbH, Mingtai Chemical Co., Ltd Roquette Pharma, Syntapharm, Südzucker) [12]. Використовували зразки мікрокристалічної целюлози (МКЦ) торгової марки Vivapur, виробник JRS Pharma.

Фармацевтичні фрактори та їх рівні, вивчені 3 метою вибору раціональних ДР для отримання таблеток екстракту грушанки круглолистої, наведено в таблиці 1.

При створенні таблеток грушанки методом прямого пресування для вивчення впливу 27 ДР речовин на фрармако-технологічні показники сумішей для таб-

Таблиця 1. Допоміжні речовини, які вивчали при розробці складу таблеток на основі сухого екстракту грушанки круглолистої методом прямого пресування

\begin{tabular}{|c|c|}
\hline Фактори & Рівні фракторів \\
\hline $\begin{array}{l}\text { A - наповнювачі на основі неорганічних } \\
\text { солей }\end{array}$ & $\begin{array}{l}a_{1}-\text { неуселін US } 2 \\
a_{2}-\text { магній оксид гранульований } \\
a_{3}-\text { кальцій гідрфоосфат безводний }\end{array}$ \\
\hline В - змащувальні речовини & $\begin{array}{l}b_{1}-\text { магній стеарат } \\
b_{2}-\text { кальцій стеарат } \\
b_{3}-\text { натрій стеарилфумарат }\end{array}$ \\
\hline C - розпушувачі & $\begin{array}{l}c_{1}-\text { натрій кроскармелоза } \\
c_{2}-\text { натрій карбоксиметилкрохмаль } \\
c_{3}-\text { крохмаль картопляний }\end{array}$ \\
\hline $\begin{array}{l}D \text { - наповнювачі на основі МКЦ та її } \\
\text { комбініцій }\end{array}$ & $\begin{array}{l}d_{1}-\text { Vivapur } 102 \\
d_{2}-\text { Vivapur } 112 \\
d_{3}-\text { Vivapur } 200 \\
d_{4}-\text { Prosolv SMCC } 90 \\
d_{5}-\text { Prosolv EASYtab SP } \\
d_{6}-\text { MKЦ бypCT } \\
d_{7}-\text { Prosolv ODT G2 } \\
d_{8}-\text { Vivapur } 302 \\
d_{9}-\text { Vivapur } 14\end{array}$ \\
\hline E - наповнювачі на основі цукрів & $\begin{array}{l}e_{1}-\text { таблетоза } 80 \\
e_{2}-\text { лудіпрес } \\
e_{3}-\text { парлітол } 200 \text { SD } \\
e_{4}-\text { Cотрri M3 } \\
e_{5}-\text { парлітол } 100 \text { SD - манітол } \\
e_{6}-\text { парлітол } 25 \text { C } \\
e_{7}-\text { парлітол } 300 \text { DC - манітол } \\
e_{8}-\text { фрловлакс } \\
e_{9}-\text { фрруктоза }\end{array}$ \\
\hline
\end{tabular}

ISSN 2312-0967. Pharmaceutical review. 2018. № 2 
Фармацевтична технологія, біофармація, гомеопатія Pharmaceutical technology, biopharmacy, homeopathy

летування використовували греко-латинський куб 2-го порядку та вивчали 5 факторів, три з яких взяті на 3-ох рівнях та два з яких на 9-ти рівнях [13].

В цьому випадку замість 2187 (3×3×3×9x9=2187) серій дослідів, які необхідно реалізувати при традиційному експерименті, коли здійснюється повний перебір всіх можливих комбінацій між рівнями 5 фракторів, реалізовано всього 54 серії дослідів (27 серій в двох повторностях).

ДР поділено на фрактори за певними критеріями, а саме, відношення їх до певної технологічної класифікації - наповнювачі на основі неорганічних солей (фактор A), змащуючі (фактор В), розпушувачі (фактор C), наповнювачі на основі МКЦ та її комбініцій (фактор D), наповнювачі на основі цукрів (фактор E).

Порошкові маси готували за класичною схемою виробництва таблеток. 3 метою розробки оптимального складу таблеток з екстрактом грушанки круглолистої методом прямого пресування було використано наступні технологічні операції: просіювання, зважування, змішування, опудрювання, пресування. Модельні суміші готували наступним чином: всі необхідні компоненти зважували, просіювали, до наповнювача на основі цукрів додавали відважену діючу речовину - екстракт грушанки круглолистої сухий, перемішували, до отриманої суміші вводили наповнювач на основі мікрокристалічної целюлози, знову перемішували, додавали наповнювач на основі неорганічних солей, змішували до однорідності, додавали розпушувач та обпудрювали змащувальною речовиною. Суміш порошків перемішували та досліджували їі фрармако-технологічні властивості - текучість $\left(\mathrm{y}_{1}\right)$, вільну насипну густину $\left(\mathrm{y}_{2}\right)$ та насипну густину після усадки $\left(\mathrm{y}_{3}\right)$, кут природного укосу $\left(\mathrm{y}_{4}\right)$, індекс Кара $\left(\mathrm{y}_{6}\right)$. Після цього пресували таблетки на лабораторній таблетній машині з діаметром пуансонів 12 мм і середньою массою таблетки 0,6 г та досліджували процес таблетування $\left(\mathrm{y}_{5}\right)$.

Матрицю планування експерименту та результати дослідження фрармако-технологічних показників якості порошкових мас для таблетування у кожній серії дослідів було реалізовано в двох повторностях, що наведено в таблиці 2.

Отримані результати підлягали дисперсійному аналізу за схемою п'ятифакторного експерименту, обчислювальна процедура якого наведена в монограсрії [13]. У тих випадках, коли експериментальне значення F-критерію було вище табличного, робили висновки про статистичну значущість досліджуваного фрактора, будували рисунки та здійснювали обговорення отриманих результатів. У випадку, коли F-критерій був нижче табличного, приймали до уваги, що між рівнями незначущого фрактора немає різниці на досліджуваний показник. Це означає, що будь-яка ДР із вивченої групи дає однаковий результат на досліджуваний показник якості порошкових мас та процес таблетування.
Результати й обговорення. Дисперсійний аналіз експериментальних даних показав, що на текучість суміші для таблетування впливають всі фактори. Вплив фракторів на досліджуваний показник якості суміші з екстрактом грушанки круглолистої можна проілюструвати наступним рядом: $\mathrm{E}>\mathrm{D}>\mathrm{C}>\mathrm{B}>\mathrm{A}$.

Найбільш суттєвий вплив на текучість проявляє природа наповнювачів на основі цукрів (рис. 1). Аналогічно будували діаграми для інших статистично значущих фракторів. Найкращу текучість порошкових мас забезпечує фруктоза (15,69 c/100г) наступними в ряді речовин є Compri M3 (17,03 c/100г), які мають перевагу над парлітолом 300 DC-манітолом (18,61 c/100г), фрловлаксом (18,95 с/100г), лудіпресом (19,93 с/100г), таблетозою 80(21,16 c/100г), парлітолом 100SD-манітолом (21,44 c/100г), парлітолом 200SD (21,64 c/100г), незадовільні показники текучості показав парлітол 25 C (143,09 c/100г).

Вплив фрактора D - наповнювачів на основі мікрокристалічної целюлози на текучість сумішей для таблетування можна зобразити наступним ранжируваним рядом переваг: Vivapur 200 (16,53 с/100г) > Procolv SMCC 90 (16,96 c/100r) > Vivapur 302 $(19,76$ c/100г) > Procolv EASYtab SP $(20,2$ c/100г) > Vivapur 14 (20,51 c/100r) > Vivapur 102 (22 c/100r) > Vivapur 112 (42,87 c/100г) > МКЦ бурст(60,81 c/100г) > Procolv ODT G2 (77,89 c/100r).

Ранжований ряд переваг впливу розпушувачів на текучість порошкових мас екстракту грушанки круглолистої має наступний вигляд: крохмаль картопляний $(31,69$ c/100г) > натрій карбоксиметилкрохмаль (32,59 c/100г) > натрій кроскармелоза (40,50 c/100г).

Серед вивчених наповнювачів на основі неорганічних солей найкращі показники текучості порошкових мас на основі екстракту грушанки круглолистої забезпечує неуселін US 2 (30,53 c/100г), який має невелику перевагу над кальцієм гідрофросфатом безводним (31,69 c/100г) та магнію оксидом гранульованим (36,97 с/100г).

Найкращу текучість порошкових сумішей серед групи змазуючих речовин забезпечує кальцію стеарат (26,7 c/100г), який має перевагу над магнію стеаратом $(33,48 \mathrm{c/100г)}$ та натрію стеарилфумаратом (39,00 c/100r).

Вплив фракторів, які впливали на кут природнього укосу порошкової суміші на основі екстракту грушанки круглолистої, має наступний вигляд: $\mathrm{E}>\mathrm{C}>\mathrm{D}>\mathrm{B}$ $>$ A.

Найменший показник кута природнього укосу таблетованої маси з екстрактом грушанки круглолистої серед вивчених наповнювачів на основі цукрів спостерігається при використанні фрруктози $\left(33,16^{\circ}\right)$ який має перевагу над Compri M3 $\left(33,5^{\circ}\right)$, фрловлаксом $\left(37,5^{\circ}\right)$, таблетозою $80\left(38,5^{\circ}\right)$, парлітолом 300 DCманітолом $\left(3^{\circ}\right)$, парлітолом 100SD-манітолом $\left(39,67^{\circ}\right)$, лудіпресом $\left(39,67^{\circ}\right)$, парлітолом 200SD $\left(39,5^{\circ}\right)$, парлітолом 25 C $\left(58^{\circ}\right)$.

ISSN 2312-0967. Фармацевтичний часопис. 2018. № 2 
Фармацевтична технологія, біофармація, гомеопатія

Pharmaceutical technology, biopharmacy, homeopathy

\begin{tabular}{|c|c|c|c|c|c|c|c|c|c|c|c|c|c|c|c|c|c|c|c|c|c|c|c|c|c|c|c|c|}
\hline & $>0$ & $\begin{array}{l}\vec{f} \\
\stackrel{f}{f} \\
-1\end{array}$ & 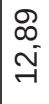 & 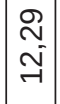 & $\begin{array}{l}2 \\
-7 \\
0 \\
0 \\
-1\end{array}$ & $\begin{array}{l}\stackrel{2}{ } \\
\underset{\sim}{-}\end{array}$ & $\begin{array}{l}\infty \\
\infty \\
\infty \\
-\infty \\
-1\end{array}$ & 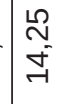 & $\begin{array}{l}0 \\
-1 \\
0 \\
0\end{array}$ & $\begin{array}{l}\text { N } \\
\text { I } \\
\text { Th }\end{array}$ & $\begin{array}{l}\stackrel{2}{\mathfrak{N}} \\
\underset{\sim}{-}\end{array}$ & \begin{tabular}{|l} 
\\
$\sigma$ \\
$\omega^{\circ}$
\end{tabular} & $\begin{array}{l}0 \\
0 \\
0 \\
-1\end{array}$ & $\begin{array}{l}\stackrel{\sim}{N} \\
\stackrel{+}{-}\end{array}$ & 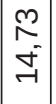 & $\begin{array}{l}3 \\
6 \\
0^{-} \\
-1\end{array}$ & $\begin{array}{l}\stackrel{N}{+} \\
0^{-0} \\
-1\end{array}$ & $\mid \begin{array}{l}-1 \\
0 \\
0 \\
-1\end{array}$ & $\begin{array}{l}\mathrm{r} \\
\stackrel{5}{\rho^{\circ}}\end{array}$ & $\begin{array}{c}\hat{f} \\
\tilde{m} \\
\rightarrow\end{array}$ & $\begin{array}{l}\Omega \\
2 \\
- \\
-1\end{array}$ & 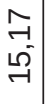 & $\begin{array}{l}\widetilde{N} \\
\tilde{m} \\
- \\
-\end{array}$ & 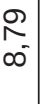 & 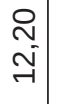 & $\begin{array}{l}\text { r } \\
- \\
-1\end{array}$ & 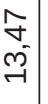 & $\begin{array}{l}\stackrel{2}{2} \\
-7 \\
-1\end{array}$ \\
\hline & $\lambda^{\circ}$ & $\begin{array}{l}-1 \\
y \\
\text { fo }\end{array}$ & $\mid$\begin{tabular}{l}
$\tilde{f}$ \\
\multirow{H}{*}{}
\end{tabular} & 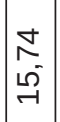 & $\begin{array}{l}\infty \\
\infty \\
\infty \\
\sigma^{-}\end{array}$ & $\begin{array}{l}\stackrel{2}{2} \\
-7 \\
-7\end{array}$ & $\begin{array}{l}\hat{0} \\
\tilde{N} \\
\tilde{N}\end{array}$ & $\mid \begin{array}{l}m \\
0 \\
0 \\
-1\end{array}$ & $\left|\begin{array}{l}n \\
-1 \\
0 \\
-1\end{array}\right|$ & $\begin{array}{l}\stackrel{L}{N} \\
\underset{\sim}{-}\end{array}$ & $\begin{array}{l}\hat{m} \\
\vec{f}\end{array}$ & $\mid \begin{array}{l}n \\
ન \\
ન \\
-1\end{array}$ & 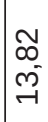 & $\begin{array}{l}\stackrel{2}{\mathbb{N}} \\
\underset{\sim}{-}\end{array}$ & $\begin{array}{l}\vec{D} \\
\tilde{N} \\
N\end{array}$ & $\begin{array}{l}\mathbb{N} \\
\text { m. } \\
\end{array}$ & $\begin{array}{l}\mathbb{N} \\
\infty \\
\rightarrow-1\end{array}$ & $\begin{array}{l}m \\
m \\
m \\
\end{array}$ & $\begin{array}{l}8 \\
\dot{i}\end{array}$ & $\begin{array}{l}\tilde{y} \\
\stackrel{-}{-} \\
\vec{G}\end{array}$ & $\begin{array}{l}0 \\
0 \\
0 \\
- \\
-1\end{array}$ & $\begin{array}{l}\stackrel{g}{+} \\
\underset{7}{7}\end{array}$ & & $\begin{array}{c}m \\
\overrightarrow{-} \\
\sigma\end{array}$ & $\begin{array}{l}2 \\
- \\
\exists \\
-1\end{array}$ & & \begin{tabular}{l}
$n$ \\
\multicolumn{1}{c}{} \\
6 \\
-1 \\
-1
\end{tabular} & 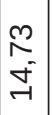 \\
\hline & $\lambda^{\infty}$ & L & $\omega$ & L & 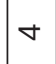 & 10 & $\sim$ & م & L & $\nabla$ & L & $\nabla$ & ما & เ & L & 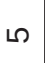 & $m$ & L & $\nabla$ & เ & $\nabla$ & L & $\nabla$ & ऽ & L & ๑ & 几 & م \\
\hline & $\lambda^{\infty}$ & เ & 10 & L & م & 10 & $m$ & م & L & م & L & م & L & レ & ا & \llcorner & $\nabla$ & ا & 几 & ऽ. & $\nabla$ & م & ת & ऽ & ـ & レ & ऽ & レ \\
\hline & $\lambda^{+}$ & \& & \& & q & m & 断 & 8 & 우 & 导 & q & $\vec{m}$ & q & 㞧 & m & $\vec{\gamma}$ & $\vec{\forall}$ & 8 & 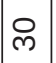 & \& & 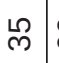 & 8 & లి & ले & m & 岕 & 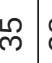 & $\begin{array}{c}\infty \\
m\end{array}$ & $\hat{m}$ \\
\hline $\mid$ & $\lambda^{+}$ & iq & q & প্লি & $\hat{m}$ & q & |용 & iq & $\vec{\gamma}$ & 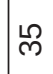 & 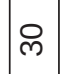 & fo & $\mathcal{F}$ & q & $m$ & q & 员 & 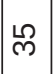 & $\stackrel{m}{+}$ & ৪) & ㅇำ & ిొ & $\widetilde{N}$ & 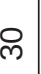 & 우 & ஓ) & ᄂ? & 우 \\
\hline 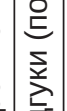 & $>$ & 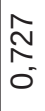 & $\mid \begin{array}{l}8 \\
? \\
0 \\
0\end{array}$ & $\mid \begin{array}{l}\hat{0} \\
0 \\
0\end{array}$ & $\begin{array}{c}\text { N } \\
\text { o }\end{array}$ & $\begin{array}{l}8 \\
\infty \\
0 \\
0\end{array}$ & $\begin{array}{l}8 \\
\infty \\
0 \\
0\end{array}$ & $\begin{array}{l}8 \\
\infty \\
0 \\
0 \\
0\end{array}$ & 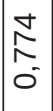 & $\begin{array}{l}\infty \\
\mathbb{N} \\
\infty \\
0 \\
0\end{array}$ & $\mid \begin{array}{l}8 \\
\infty \\
0 \\
0\end{array}$ & $\mid \begin{array}{l}\infty \\
\infty \\
\infty \\
0 \\
0\end{array}$ & $\begin{array}{l}8 \\
0 \\
0 \\
0\end{array}$ & $\begin{array}{l}8 \\
\infty \\
0 \\
0\end{array}$ & $\begin{array}{c}\infty \\
\sim \\
\infty \\
0 \\
0\end{array}$ & $\begin{array}{c}8 \\
0 \\
0 \\
0\end{array}$ & 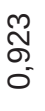 & $\mid \begin{array}{l}0 \\
\infty \\
\infty \\
0 \\
0\end{array}$ & 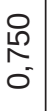 & $\left|\begin{array}{c}0 \\
\stackrel{1}{2} \\
0 \\
0\end{array}\right|$ & $\begin{array}{l}8 \\
0 \\
0 \\
0 \\
0\end{array}$ & $\begin{array}{c}1 \\
\infty \\
\infty \\
0 \\
0\end{array}$ & $\begin{array}{c}\stackrel{N}{N} \\
0^{-}\end{array}$ & $\begin{array}{c}t \\
⿱ 亠 䒑 \\
0^{-}\end{array}$ & 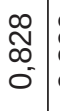 & $\begin{array}{l}8 \\
0 \\
0 \\
0\end{array}$ & $\begin{array}{c}0 \\
\stackrel{2}{2} \\
0^{\circ}\end{array}$ & $\begin{array}{l}8 \\
8 \\
\infty \\
0 \\
0\end{array}$ \\
\hline & $>^{m}$ & 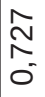 & $\mid \begin{array}{c}\mathcal{N} \\
\mathbb{N} \\
0\end{array}$ & $\mid \begin{array}{l}0 \\
0 \\
0 \\
0 \\
0\end{array}$ & $\begin{array}{l}8 \\
\infty \\
0 \\
0\end{array}$ & $\mid \begin{array}{l}8 \\
0 \\
0 \\
0 \\
0\end{array}$ & $\mid \begin{array}{l}\infty \\
\infty \\
\infty \\
0 \\
0\end{array}$ & $\begin{array}{l}8 \\
8 \\
0 \\
0 \\
0\end{array}$ & $\begin{array}{c}\text { 界 } \\
0^{-}\end{array}$ & $\begin{array}{l}8 \\
8 \\
0 \\
0\end{array}$ & $\mid \begin{array}{c}0 \\
N \\
0^{-}\end{array}$ & 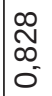 & $\mid \begin{array}{c}\text { N } \\
\hat{a} \\
0^{\circ}\end{array}$ & $\begin{array}{l}8 \\
0 \\
\infty \\
0\end{array}$ & $\begin{array}{l}\tilde{N} \\
\tilde{O} \\
\tilde{0}\end{array}$ & 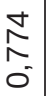 & $\begin{array}{l}\mathscr{8} \\
0 \\
\infty \\
0 \\
0\end{array}$ & $\begin{array}{l}\tilde{N} \\
\tilde{O} \\
\tilde{O}\end{array}$ & $\begin{array}{l}8 \\
8 \\
\infty \\
0 \\
0\end{array}$ & $\left|\begin{array}{c}\stackrel{0}{1} \\
2 \\
0\end{array}\right|$ & $\begin{array}{l}0 \\
0 \\
0 \\
0 \\
0\end{array}$ & $\begin{array}{l}1 \\
0 \\
\infty \\
0 \\
0\end{array}$ & & $\begin{array}{c}8 \\
\infty \\
0 \\
0\end{array}$ & $\begin{array}{l}8 \\
8 \\
0 \\
0^{-1}\end{array}$ & \begin{tabular}{c}
\multirow{2}{*}{} \\
$0^{\prime}$
\end{tabular} & 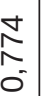 & 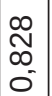 \\
\hline & $>^{N}$ & $\begin{array}{l}0 \\
0 \\
0 \\
0 \\
0\end{array}$ & $\mid \begin{array}{l}0 \\
0 \\
0 \\
0 \\
0\end{array}$ & $\mid \begin{array}{l}1 \\
\infty \\
\infty \\
0 \\
0\end{array}$ & $\mid \begin{array}{l}g \\
0 \\
0 \\
0\end{array}$ & $\mid \begin{array}{l}\mathscr{0} \\
0 \\
0 \\
0\end{array}$ & $\begin{array}{l}g \\
0 \\
0 \\
0\end{array}$ & $\begin{array}{l}0 \\
0 \\
0 \\
0 \\
0\end{array}$ & $\mid \begin{array}{l}9 \\
0 \\
0 \\
0\end{array}$ & $\begin{array}{l}\hat{N} \\
\hat{N}\end{array}$ & $\mid \begin{array}{l}0 \\
0 \\
0 \\
0 \\
0\end{array}$ & $\mid \begin{array}{l}0 \\
0 \\
0 \\
0\end{array}$ & $\begin{array}{l}\hat{\theta} \\
0 \\
0\end{array}$ & $\begin{array}{l}0 \\
\infty \\
0 \\
0 . \\
0\end{array}$ & $\left|\begin{array}{l}0 \\
0 \\
0 \\
0\end{array}\right|$ & $\begin{array}{l}\hat{0} \\
\mathscr{E} \\
0 \\
0\end{array}$ & $\begin{array}{l}\text { 员 } \\
0^{\circ}\end{array}$ & $\mid \begin{array}{l}8 \\
0 \\
0 \\
0\end{array}$ & $\begin{array}{l}\mathbb{N} \\
\tilde{\tilde{C}} \\
0 \\
0\end{array}$ & $\begin{array}{l}9 \\
0 \\
0 \\
0\end{array}$ & $\begin{array}{l}\text { Ln } \\
0 \\
0 \\
0 \\
0 \\
0\end{array}$ & $\begin{array}{c}\underset{N}{N} \\
0_{0}^{\prime}\end{array}$ & & \begin{tabular}{l}
0 \\
\hdashline \\
$0^{-}$
\end{tabular} & $\begin{array}{c}\underset{N}{\mathbb{N}} \\
0^{-}\end{array}$ & & $\begin{array}{l}9 \\
0 \\
0 \\
0\end{array}$ & $\begin{array}{l}\stackrel{8}{\ell} \\
0^{\prime}\end{array}$ \\
\hline & $\lambda^{N}$ & $\begin{array}{l}0 \\
0 \\
6 \\
0 \\
0\end{array}$ & $\begin{array}{l}8 \\
0 \\
0 \\
0\end{array}$ & $\mid \begin{array}{l}\infty \\
1 \\
0 \\
0 \\
0\end{array}$ & $\begin{array}{l}9 \\
0 \\
0 \\
0\end{array}$ & 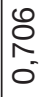 & $\begin{array}{l}\tilde{N} \\
0 \\
0 \\
0\end{array}$ & $\begin{array}{l}\hat{\theta} \\
0 \\
0\end{array}$ & $\mid \begin{array}{l}9 \\
0 \\
0 \\
0\end{array}$ & $\begin{array}{l}0 \\
0 \\
0 \\
0 \\
0\end{array}$ & $\mid \begin{array}{l}0 \\
0 \\
0 \\
0 \\
0\end{array}$ & $\left|\begin{array}{l}0 \\
0 \\
0 \\
0\end{array}\right|$ & $\begin{array}{l}\hat{0} \\
0 \\
0\end{array}$ & $\mid \begin{array}{l}0 \\
0 \\
0 \\
0\end{array}$ & $\left|\begin{array}{l}8 \\
0 \\
0 \\
0\end{array}\right|$ & $\begin{array}{l}\hat{0} \\
0 \\
0 \\
0\end{array}$ & $\begin{array}{l}\underset{N}{N} \\
0_{0}^{-}\end{array}$ & $\left|\begin{array}{l}8 \\
0 \\
0 \\
0 \\
0\end{array}\right|$ & $\begin{array}{l}\mathbb{N} \\
\widetilde{0} \\
0 \\
0\end{array}$ & $\begin{array}{l}9 \\
0 \\
0 \\
0\end{array}$ & $\begin{array}{l}8 \\
0 \\
0 \\
0\end{array}$ & $\begin{array}{l}0 \\
\stackrel{R}{R} \\
0^{-}\end{array}$ & $\begin{array}{l}0 \\
0 \\
0 \\
0 \\
0\end{array}$ & $\begin{array}{c}\underset{N}{N} \\
0^{-}\end{array}$ & 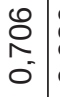 & & 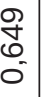 & 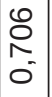 \\
\hline & $>$ & 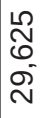 & $\begin{array}{l}\tilde{m} \\
\infty \\
\tilde{N} \\
\tilde{N}\end{array}$ & $\mid \begin{array}{c}\mathscr{D} \\
\infty \\
\omega \\
\infty \\
\sim \\
N\end{array}$ & $\begin{array}{l}\hat{0} \\
\varnothing \\
\infty \\
-1 \\
-1\end{array}$ & 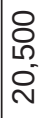 & $\begin{array}{l}\infty \\
0 \\
\mathscr{~} \\
\tilde{N} \\
\widetilde{-}\end{array}$ & 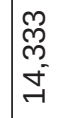 & 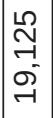 & $\begin{array}{l}0 \\
\stackrel{N}{N} \\
0 \\
0 \\
-1\end{array}$ & $\begin{array}{l}\curvearrowright \\
\curvearrowright \\
\sigma^{-} \\
-1\end{array}$ & $\begin{array}{l}\mathcal{N} \\
\mathcal{L} \\
\stackrel{2}{N} \\
\sim\end{array}$ & 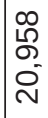 & 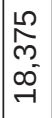 & $\mid \begin{array}{l}n \\
\infty \\
\infty \\
0 \\
-1 \\
-1\end{array}$ & 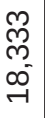 & 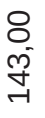 & $\left|\begin{array}{l}\vec{F} \\
\vec{g} \\
\vec{J}\end{array}\right|$ & 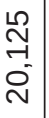 & 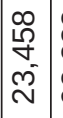 & $\begin{array}{l}\stackrel{m}{m} \\
m \\
\sigma^{-}\end{array}$ & 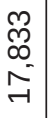 & & 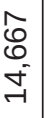 & 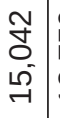 & & 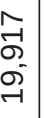 & $\begin{array}{l}\text { o } \\
\stackrel{2}{ } \\
\stackrel{-}{-1}\end{array}$ \\
\hline & $\lambda^{-1}$ & $\begin{array}{l}\stackrel{2}{N} \\
\underset{\sim}{N} \\
\text { N }\end{array}$ & $\begin{array}{l}\stackrel{8}{8} \\
\stackrel{+}{+}\end{array}$ & $\left|\begin{array}{l}\hat{\omega} \\
-1 \\
\omega \\
N\end{array}\right|$ & $\begin{array}{l}0 \\
\mathscr{0} \\
0 \\
\sigma \\
-\end{array}$ & 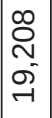 & $\begin{array}{l}m \\
m \\
m \\
\infty 0^{-} \\
\stackrel{్}{-}\end{array}$ & & $\begin{array}{l}0 \\
0 \\
0 \\
\sigma_{-1}^{-1}\end{array}$ & $\begin{array}{l}\widetilde{N} \\
\mathcal{2} \\
\tilde{L}\end{array}$ & 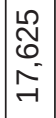 & 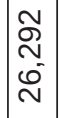 & 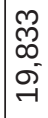 & $\begin{array}{l}\hat{\&} \\
\stackrel{0}{-} \\
-1\end{array}$ & $\begin{array}{l}\vec{A} \\
\sigma \\
\vec{J} \\
-\end{array}$ & 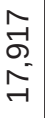 & $\begin{array}{l}\hat{0} \\
0 \\
- \\
- \\
-\end{array}$ & 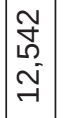 & 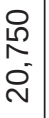 & $\begin{array}{l}\infty \\
\infty \\
\infty \\
\mathbb{D} \\
\sim \\
\sim\end{array}$ & 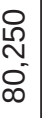 & 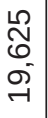 & & 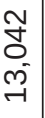 & $\begin{array}{l}\mathscr{M} \\
\mathscr{O} \\
\dot{J}^{-}\end{array}$ & & & 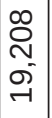 \\
\hline & $\omega$ & $\theta^{-1}$ & $e^{N}$ & $e^{\infty}$ & $e^{+}$ & $\omega^{\omega}$ & $\infty^{\circ}$ & $0^{\wedge}$ & $e^{\infty}$ & $\infty^{\circ}$ & $\omega^{\circ}$ & $\infty^{\wedge}$ & $e^{\infty}$ & $e^{\infty}$ & $e^{-1}$ & $e^{\nu}$ & $0^{\circ}$ & $e^{\top}$ & $\Phi^{\iota}$ & $\infty^{\infty}$ & $\oplus^{\circ}$ & $\mathbb{Q}^{+}$ & $\odot^{\infty}$ & $\odot^{0}$ & $0^{\wedge}$ & $e^{v}$ & $\omega^{m}$ & $e^{-1}$ \\
\hline & 0 & $0^{-1}$ & $0^{n}$ & $0^{\circ}$ & $\sigma^{N}$ & $0^{\circ}$ & 0 & $0^{m}$ & $0^{+}$ & $0^{\infty}$ & $0^{+}$ & $0^{\infty}$ & $0^{\infty}$ & $\sigma^{2}$ & $0^{\circ}$ & $8^{-1}$ & $0^{\circ}$ & $0^{\prime}$ & $\sigma^{N}$ & $0^{\wedge}$ & $\delta^{N}$ & $\gamma^{\circ}$ & $\gamma^{\infty}$ & $8^{\infty}$ & $\mathrm{O}^{+}$ & $0^{\circ}$ & $\delta^{-1}$ & $\gamma^{\circ}$ \\
\hline & 0 & $u^{-1}$ & $v^{-1}$ & $\mathrm{O}^{-1}$ & $\mathrm{v}^{-1}$ & $0^{-1}$ & $4 \mathrm{O}^{-1}$ & 4 & $\mathrm{O}^{-1}$ & $\mathrm{U}^{-1}$ & $\mathrm{U}^{N}$ & $0^{\sim}$ & $0^{n}$ & $0^{2}$ & $0^{2}$ & $0^{N}$ & $u^{\sim}$ & $0^{2}$ & $u^{N}$ & $0^{m}$ & $v^{m}$ & $0^{m}$ & $0^{\infty}$ & $0^{\infty}$ & $u^{m}$ & $0^{m}$ & $0^{m}$ & $0^{\prime \prime}$ \\
\hline & $\infty$. & $e^{-1}$ & $e^{N}$ & $e^{m}$ & $\Omega^{-1}$ & $e^{2}$ & $e^{\infty}$ & $\theta^{-1}$ & $e^{N}$ & $e^{\infty}$ & $e^{-1}$ & $e^{\infty}$ & $e^{n}$ & $0^{-1}$ & $e^{v}$ & $e^{n}$ & $e^{-1}$ & $e^{v}$ & $e^{\infty}$ & $\theta^{-1}$. & $\Omega^{N}$ & $e^{n}$ & $\Omega^{-1}$ & $0^{N}$ & $2^{m}$. & $0^{-1}$. & $0^{N}$ & $0^{m}$ \\
\hline & $\varangle$ & $\sigma^{-1}$ & $\sigma^{-1}$ & $\sigma^{-1}$ & $\mid \pi^{N}$ & $\pi^{2}$ & $\sigma^{2}$ & $\sigma^{m}$ & $\pi^{m}$ & ( & $\sigma^{-1}$ & $\mid \sigma^{-1}$ & $\sigma$ & $\sigma^{2}$ & $\sigma^{2}$ & $\sigma^{2}$ & $\tau^{m}$ & $\pi^{m}$ & $\tau^{m}$ & $\sigma^{-1}$ & $\sigma^{-1}$ & $\sigma^{-1}$ & $\sigma^{2}$ & $\sigma^{0}$ & $\pi^{2}$ & $\sigma^{m}$ & $\pi^{m}$ & $\pi^{m}$ \\
\hline & & & & $m$ & $\nabla$ & & 0 & $\wedge$ & $\infty$ & a) & 귀 & -1 & สิ & $\stackrel{m}{\rightarrow}$ & 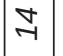 & L & $\mid \begin{array}{l}\mathscr{N} \\
-1\end{array}$ & 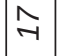 & $\stackrel{\infty}{-1}$ & $\rightarrow$ & จ & $\ddot{N}$ & & $\stackrel{m}{\sim}$ & $\stackrel{\nabla}{\sim}$ & & 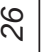 & $\hat{\imath}$ \\
\hline
\end{tabular}

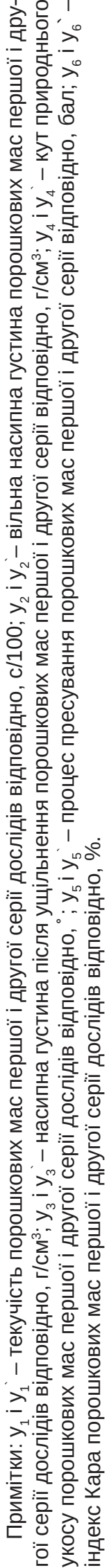

ISSN 2312-0967. Pharmaceutical review. 2018. № 2 
Фармацевтична технологія, біофармація, гомеопатія Pharmaceutical technology, biopharmacy, homeopathy

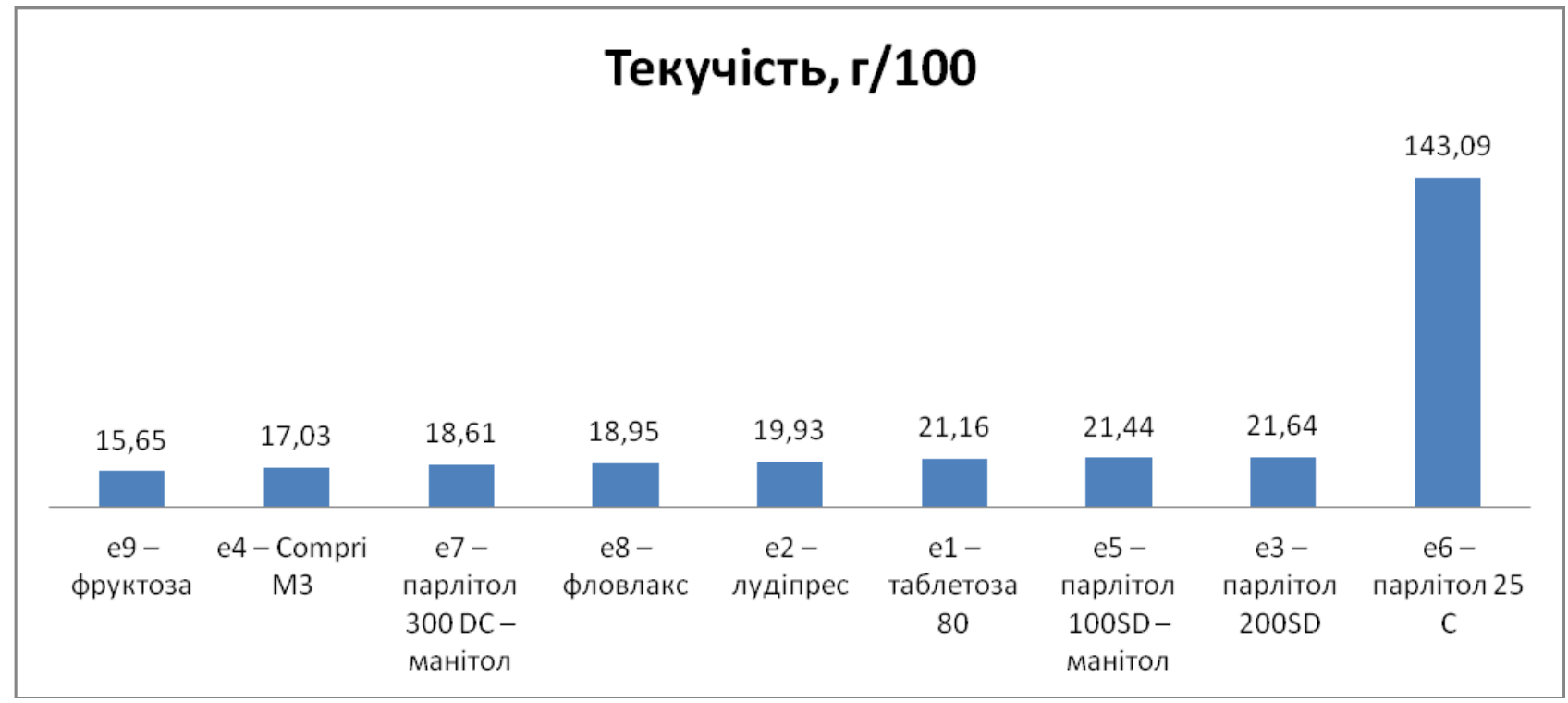

Рис. 1. Вплив наповнювачів на основі цукрів на текучість порошкових сумішей для таблетування.

Вплив розпушувачів на кут природного укосу порошкових мас із екстрактом грушанки круглолистої можна представити наступним ранжованим рядом переваг: крохмаль картопляний $(37,11)>$ натрій карбоксиметилкрохмаль $(39,77)>$ натрій кроскармелоза $(42,72)$.

Вплив наповнювачів на основі мікрокристалічної целюлози на величину кута природнього укосу сумішей для таблетування можна представити наступним ранжованим рядом переваг: vivapur $302(36,17)>$ Vivapur $200(36,67)>$ Prosolv SMCC $90\left(36,83^{\circ}\right)>$ Vivapur $14\left(37,83^{\circ}\right)>$ Prosolv EASYtab SP $(39,17)>$ Vivapur $102(40,67)>$ Prosolv ODT G2 $(42,5)>$ МКЦ бурст (43,33) > Vivapur $112(45,67)$.

Найменше значення кута природнього укосу порошкових мас з екстрактом грушанки круглолистої серед змазуючих речовин отримали при використанні магнію стеарату $(38,22)$. Наступні позиції в ряді переваг займають кальцій стеарат $(40,5)$ та натрій стеарилорумарат $(40,89)$.

При дослідженні впливу наповнювачів на основі неорганічних солей на значення кута природного укосу сумішей для таблетування екстракту грушанки круглолистої отримали наступні результати: неуселін US2 $(38,61)$, магнію оксид гранульований $(39,72)$, кальцію гідрофоссрат безводний $(41,28)$.

Здатність порошкових мас до таблетування методом прямого пресування характеризує вільна насипна густина та насипна густина після усадки. Чим вищий показник вільної насипної густини та густини після усадки сумішей для таблетування, тим вищою $€$ ймовірність отримати таблетки методом прямого пресування.

Значущість фракторів, вплив яких на вільну насипну густину порошкових сумішей вивчали, можна зобразити наступним чином: $C>A>D>E$ при статис- тичній незначущості фрактори В. Ідентично впливають фрактори і на насипну густину після усадки.

Найбільше значення вільної насипної густини сумішей для таблетування з екстрактом грушанки круглолистої при дослідженні розпушуючих допоміжних речовин спостерігали при використанні натрій карбоксиметилкрохмалю $(0,697$ г/см³), який має перевагу над крохмалем картопляним $(0,682$ г/см³ $)$ та натрій кроскармелозою $(0,647$ г/см³).

При досліджені насипної густини після ущільнення найвище значення отримано при використанні крохмалю картопляного $(0,815$ г/см³), дещо поступаються натрій карбоксиметилкрохмаль $(0,793$ г/см³ $)$ та натрій кроскармелоза $(0,792$ г/см³).

Ранжований ряд переваг впливу наповнювачів на основі неорганічних солей на вільну насипну густину можна проілюструвати наступним чином: кальцію гідрофросфрат безводний $(0,697$ г/см³) $>$ крохмаль картопляний $\left(0,682\right.$ г/см $\left.{ }^{3}\right)>$ натрій кроскармелоза $\left(0,647 r / \mathrm{cm}^{3}\right)$. Вплив допоміжних речовин даної групи на насипну густину після ущільнення ідентичний: кальцію гідрофосфрат безводний $(0,815$ г/см³) > крохмаль картопляний $(0,806$ г/см³ $)>$ натрій кроскармелоза $\left(0,757 г / \mathrm{cm}^{3}\right)$.

Найбільше значення вільної насипної густини сумішей для таблетування серед наповнювачів на основі мікрокристалічної целюлози спостерігається при використанні МКЦ бурсту $(0,724$ г/см³). Наступні місця займають Prosolv ODT G2 $\left(0,697 г / \mathrm{cm}^{3}\right)$, Vivapur $302\left(0,691 \mathrm{r} / \mathrm{cm}^{3}\right)$, Vivapur $200\left(0,687 \mathrm{r} / \mathrm{cm}^{3}\right)$, Prosolv SMCC $90 \quad\left(0,684 \quad \mathrm{r}^{\mathrm{c}} \mathrm{cm}^{3}\right)$, Prosolv

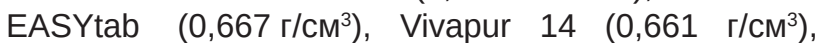
Vivapur $102\left(0,644 \mathrm{r} / \mathrm{cm}^{3}\right)$ Vivapur $112\left(0,625 \mathrm{r} / \mathrm{cm}^{3}\right)$.

Після дослідження порошкових мас на насипну густину після ущільнення високі значення серед наповнювачів на основі мікрокристалічної целюлози

ISSN 2312-0967. Фармацевтичний часопис. 2018. № 2 
отримано: МКЦ бурст $(0,854$ г/см³), Prosolv ODT G2 $\left(0,823 г / \mathrm{cm}^{3}\right)$, які мають перевагу над Vivapur 302 $\left(0,809 \mathrm{r} / \mathrm{cm}^{3}\right)$, Prosolv SMCC $90\left(0,792 \mathrm{r} / \mathrm{cm}^{3}\right)$, Vivapur

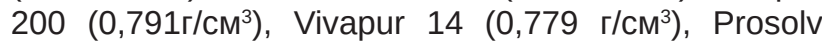

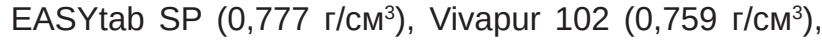
Vivapur $112\left(0,749 \mathrm{r} / \mathrm{cm}^{3}\right)$.

Найвище значення вільної насипної густини серед наповнювачів на основі цукрів забезпечує Compri M3

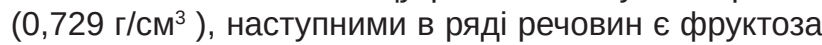
$(0,703$ г/см³), які мають перевагу над парлітолом 300

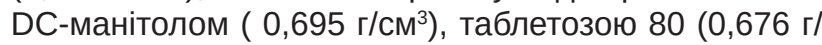
$\left.\mathrm{cm}^{3}\right)$, фрловлаксом $\left(0,664 \mathrm{r}_{\mathrm{cm}}^{3}\right)$, парлітолом 25C

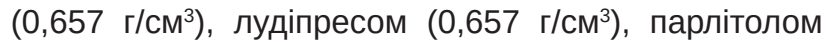

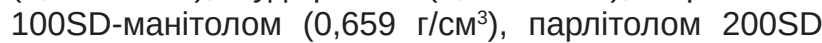
$\left(0,639\right.$ г/см $\left.{ }^{3}\right)$.

Після дослідження порошкових мас на основі екстракту грушанки круглолистої на насипну густину після ущільнення ранжований ряд переваг серед наповнювачів на основі цукрів має такий вигляд: Compri M3

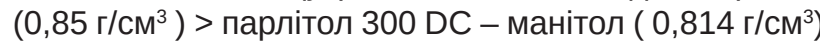

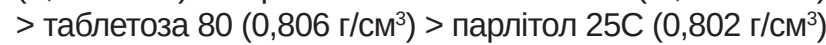

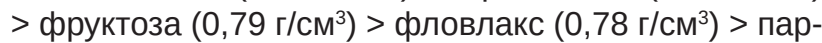

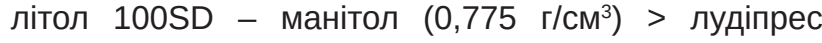

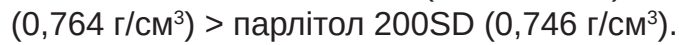

Вплив фракторів, які вивчали, на показник індексу Кара порошкової суміші на основі екстракту грушанки круглолистої має наступний вигляд: C> E при статистичній незначущості факторів A, B, D.

Найнижчий показник індексу Кара таблетованої маси з екстрактом грушанки круглолистої серед вивчених наповнювачів на основі цукрів спостерігається при використанні фрруктози (11,66 \%), який має перевагу над лудіпресом (13,99 \%), Compri M3 (14,34 \%), парлітолом 200SD (14,36 \%), парлітолом 300 DCманітолом (14,65 \%), парлітолом 100SD-манітолом $(14,94 \%)$, фрловлаксом $(15,14 \%)$, таблетозою 80 (15,62 \%), парлітолом 25 C (16,89\%).

Вплив розпушувачів на індекс Кара порошкових мас з екстрактом грушанки круглолистої можна проілюструвати наступним ранжованим рядом переваг: крохмаль картопляний $(12,52 \%)>$ натрій карбоксиметилкрохмаль $(15,74 \%)>$ натрій кроскармелоза (15,69\%).

Аналіз результатів досліджень фрармако-технологічних властивостей порошкових сумішей з екстрактом грушанки круглолистої, а саме текучості, кута природнього укосу, вільної насипної густини та насипної густини після ущільнення, індексу Кара показують, що можна використовувати метод прямого пресування.

При пресуванні таблеток на основі сухого екстракту грушанки круглолистої проведено оцінку процесу таблетування за п'ятибальною шкалою. Оцінювали процес пресування за наступними критеріями: засипка матриці, зусилля виштовхування таблеток 3 ма-
Фармацевтична технологія, біофармація, гомеопатія Pharmaceutical technology, biopharmacy, homeopathy

триці, налипання таблетної маси до прес-інструменту.

5 балів - матриця засипається однорідно, таблетна маса і таблетки не підлипають до прес-інструменту, таблетки виштовхуються без особливого зусилля.

4 бали - майже однорідно засипана матриця, на пуансонах є незначний наліт, але таблетна маса і таблетки до пуансонів не підлипають, таблетки виштовхуються $з$ докладанням зусилля.

3 бали - неоднорідно засипана матриця, таблетна маса і таблетки злегка підлипають до пуансонів, таблетка виштовхується з прикладанням зусилля.

2 бали - матриця не засипається таблетованою масою, таблетки підлипають до прес-інструменту і пошкоджуються.

Вплив вивчених фракторів на процес таблетування порошкової маси 3 екстрактом грушанки круглолистої має наступний вигляд: E>D, при незначущості фракторів, А, В та С.

Ранжований ряд переваг впливу наповнювачів на основі цукрів на процес таблетування порошкової суміші з екстрактом грушанки круглолистої має наступний вигляд: таблетоза 80 (5 балів) = парлітол 200SD (5 балів) = лудіпрес (5 балів) > Compri M3 (4,8 бала) = фрруктоза (4,8 бала) = 300 DC - манітол ( 4,8 бала) $=$ фрловлакс $(4,8$ бала) = парлітол 100SD - манітол (4,8 бала) > парлітол 25C (3,3 бала).

Найкраще процес таблетування порошкової маси з екстрактом грушанки круглолистої проходив при використанні prosolv SMCC 90 (5 балів), Vivapur 200 (5 балів), Vivapur 14 (5 балів), Prosolv EASYtab SP (5 балів), Vivapur 102 (5 балів), які мають перевагу над МКЦ бурстом (4,5 бала), Vivapur 302 (4,5 бала), Vivapur 112 (4,3 бала), Prosolv ODT G2 (4,2 бала).

Результати досліджень показали, що при пресуванні таблеток екстракту грушанки круглолистої всі серії пресувалися добре. За допомогою статистичних методів аналізу проведено дослідження впливу допоміжних речовин на фрармако-технологічні показники якості порошкових сумішей і процес таблетування та доведено, що при раціональному поєднанні допоміжних речовин доцільно використовувати метод прямого пресування для отримання таблеток на основі екстракту грушанки круглолистої.

Висновки. 1. За допомогою греко-латинського кубу 2-го порядку вивчено вплив 27-ми ДР на фрармако-технологічні властивості порошкових мас (плинність, кут природного укосу, вільну насипну густину, насипну густину після ущільнення) і процес пресування таблеток з екстрактом листя грушанки круглолистої.

2. Аналіз фрармако-технологічних показників порошкових мас екстракту грушанки круглолистої з ДР вказують на можливість отримання таблеток методом прямого пресування.

ISSN 2312-0967. Pharmaceutical review. 2018. № 2 
Фармацевтична технологія, біофармація, гомеопатія

Pharmaceutical technology, biopharmacy, homeopathy

\title{
ИССЛЕДОВАНИЕ ВЛИЯНИЯ ВСПОМОГАТЕЛЬНЫХ ВЕЩЕСТВ НА ФАРМАКО-ТЕХНОЛОГИЧЕСКИЕ СВОЙСТВА ПОРОШКОВЫХ МАСС ПРИ РАЗРАБОТКЕ ТЕХНОЛОГИИ ТАБЛЕТОК ЭКСТРАКТА ГРУШАНКИ КРУГЛОЛИСТОЙ
}

\author{
Н. П. Дарзули, Т. А. Грошовыйㅁ, Е. В. Соколова², Е. А. Подплетняя² \\ ГВУЗ «Тернопольский государственный медицинский университет имени И. Я. Горбачевского Мз \\ Украины» ${ }^{1}$ \\ ГУ «Днепропетровская медицинская академия МЗ Украины»² \\ darzulinp@tdmu.edu.ua
}

Цель работы. Исследование влияния вспомогательных веществ на фрармако-технологические свойства порошковых масс для таблетирования при разработке таблеток на основе сухого экстракта грушанки круглолистой. Материалы и методы. В процессе исследований использованы сухой экстракт грушанки круглолистой и 27 вспомогательных веществ пяти технологических групп. Изучение влияния вспомогательных веществ на фрармакотехнологические показатели качества таблеток, такие как: угол естественного откоса, насыпную плотность до и после усадки, текучесть проводили согласно требованиям ГФу 2 издания. Процесс таблетирования оценивали по пятибалльной шкале.

Результаты и обсуждение. При создании таблеток методом прямого прессования изучено влияния 27 вспомогательных веществ на фрармако-технологические показатели смесей для таблетирования. Исследования проведены с использование математического планирования эксперимента - греко-латинского куба 2-го порядка. Результаты дисперсионного анализа экспериментальных данных показали, что лучшую текучесть порошковых масс с экстрактом грушанки круглолистой обеспечивают фрруктоза, Vivapur 200, крахмал картофельный, неусилин US 2 и кальция стеарат.

Наименьшее значение угла естественного откоса порошковых масс с экстрактом грушанки круглолистой получали при использовании фрруктозы, крахмала картофрельного, МКЦ 302, неусилина US 2 и магния стеарата.

Наибольшее значение свободной насыпной плотности порошковых масс с экстрактом грушанки круглолистой получали при использовании сахара Compri M3, натрий карбоксиметилкрахмала, крахмала картофельного, кальция гидрофроссрата безводного, МКЦ бурст, а насыпной плотности после усадки - сахара Сompri M3, крахмала картофельного, кальция гидрофосфрата безводного, МКЦ бурст.

Наилучшие значения показателя индекса Кара получали при использовании крахмала картофельного и фруктозы. Лучше процесс прессования таблеток происходил при использовании таблетозы, парлитола 200 SD, лудипреса, Prosolv SMCC 90, Vivapur 200, Vivapur 14 Prosolv EASYtab SP, Vivapur 102.

Выводы. С помощью греко-латинского куба 2-го порядка изучено влияние 27-ми ВВ на фрармако-технологические свойства порошковых масс (текучесть, угол естественного откоса, свободную насыпную плотность, насыпную плотность после уплотнения) и процесс прессования таблеток с экстрактом листьев грушанки круглолистной.

Анализ фрармако-технологических показателей порошковых масс экстракта грушанки круглолистный со ВВ указывают на возможность получения таблеток методом прямого прессования.

Ключевые слова: таблетки; фрармако-технологические показатели порошковых масс; растительные экстракты; грушанка круглолистая, математическое планирование эксперимента.

\section{INVESTIGATION OF THE EFFECTS OF EXCIPIENTS ON TECHNOLOGICAL PROPERTIES OF COMPRESSION MIXTURE IN THE DEVELOPMENT OF TABLET TECHNOLOGY ROUND-LEAVED WINTERGREEN EXTRACT}

\author{
N. P. Darzuli ${ }^{1}$, T. A. Hroshovyi ${ }^{1}$, K. V. Sokolova ${ }^{2}$, O. A. Podpletnia ${ }^{2}$ \\ I. Horbachevsky Ternopil State Medical University ${ }^{1}$ \\ State Establishment "Dnipropetrovsk Medical Academy of Health Ministry of Ukraine"2 \\ darzulinp@tdmu.edu.ua
}

The aim of the work. Investigation of the influence of substances on the technological properties of compression mixture for compressing in the development of tablets Pyrola Rotundifolia extract.

Materials and Methods. Dry extract of round-leaved wintergreen and 27 excipients of five technological groups were used. Studying of the influence of substances on the technological properties of the quality of tablets, such as: the angle of the natural slope, flowability, the bulk density of the compression mixture were carried out in accordance with the requirements of the State Pharmacopoeia. The tabletting process was evaluated on a five-point scale.

ISSN 2312-0967. Фармацевтичний часопис. 2018. № 2 
Results and Discussion. Tablets was obtained by direct compression to study the effect of 27 substances on the technological properties of the compression mixture. The Greek-Latin cube of the 2 nd order was used.

The results of the dispersion analysis of the experiment showed that the best flow of compression mixture was provided by fructose, microcrystalline cellulose (MCC) 200, potato starch, neusilin US 2 and calcium stearate.

The smallest value of the angle of natural slope of compression mixture was obtained using fructose, potato starch, MCC 302, neusilin US 2 and magnesium stearate.

The greatest value of free bulk density compression mixture treated using sodium carboxymethyl starch, CompriM3, potato starch, calcium hydrogen phosphate anhydrous, MCC burst.

The greatest value of bulk density after shrinkage Compri M3, potato starch, calcium hydrogen phosphate anhydrous, MCC burst.

The best values of the Kara index were obtained using potato starch and fructose.

The tablet compression process is best done with the use of tabletosis, parlitol 200SD, ludipress, procolv SMCC 90, MCC 200, vivapur 14, procolv EASYtab SP, vivapur 102.

Conclusions. The influence of 27 excipients on the technological properties of compression mixture (the angle of the natural slope, flowability, the bulk density, process of tableting) were studied. The technological properties of the compression mixture of extract of round-leaved wintergreen and excipients indicate the ability to obtain tablets by direct compression.

Key words. tablets; technological properties; compression mixture, extracts of Pyrola Rotundifolia L.; round-leaved wintergreen; mathematical planning of the experiment.

\section{Список літератури}

1. Практическая урология : рук. для врачей / под ред. П. В. Глыбочко, Ю. Г. Аляева. - М. : Медфорум, 2012. $352 \mathrm{C}$.

2. Пасєчніков С. П. Фітопрепарати в лікуванні урологічних і несррологічних захворювань / С. П. Пасєчніков, B. О Попов // Medical Nature. - 2012. № 2 (10). - C. 76 - 81.

3. Мониторинг отношения потребителей к применению препаратов растительного происхождения / Б. П. Громовик, Е.В.Юрченко, С. С. Павличко [и др.] // Провизор. - 2000. - № 14. - С. 14-16.

4. Гарник Т. П. Сучасні технології виробництва фрітозасобів та перспективи фрітотерапії / Т. П. Гарник // Фітотерапія. Часопис. - 2008. - № 1. - С. 59 -63.

5. Вичкуткина Е. А. Создание фритосбора «Нефролен» с использованием рационального химико-фрармакологического подхода: автореф. дис. на соискание науч. степени канд. фрармац. наук / Е. А. Вичкуткина. - Пермь, 2007. -27 c.

6. Пензина Т. Н. Фармакологическая активность некоторых растений семейства грушанковых : автореф. дис. на здобуття наук. ступеня канд. фрармац. наук / Т. Н. Пензина. - Барнаул, 1999. - 24 с.

7. Мазепина Л. С. Обоснование применения грушанки - традиционного урологического средства / Л. Мазепина, А. Иванов, Н. Фурса // Вестник Пермской государственной фрармацевтической академии. - 2010. - № 7. - С. 224-226.

\section{References}

1. Glybochko PV, Alyaev YuG. Practical urology: manual for doctors. [Практическая урология руководство для врачей] Medforum; 2012. Russian.

2. Pasechnikov SP, Popov VO. [Phytodrugs in the treatment of urological and nephrological diseases] Medical Nature. 2012;2(10): 76-81. Ukrainian.

3. Hromovik BP, Yurchenko EV, Pavlychko SS. [Monitoring consumer attitudes towards the use of herbaldrugs]
8. Дарзулі Н. П. Використання грушанки круглолистої в медицині та орармації, перспективи створення нових лікарських засобів на її основі / Н. П. Дарзулі, Т. А. Грошовий // Фітотерапія. Часопис. - 2015. - № 3. - С. 55-58.

9. Брюханов В. М. Влияние растений семейства грушанковых на фуннцию почек в эксперименте / В. Брюханов, Я. Зверев, Е. Санаров // Фармация. 1997. - № 4. - C. 41-42.

10. Darzuli N. P. Marketing research of the market of drugs and dietary supplements used for treatment of inflammatory diseases of the urinary system / N. P. Darzuli, A. I. Denys, T. A. Hroshovyi // Pharmaceutical Review. - 2017. - No. 4. - P. 7681.

11. Державна Фармакопея України: в 3 т. / Державне підприємство «Український науковий фрармакопейний центр якості лікарських засобів». - 2е вид. - Харків : Державне підприємство «Український науковий фармакопейний центр якості лікарських засобів», 2015. - T. 1. -1128 c.

12. Допоміжні речовини у виробництві ліків : навч. посіб. для студентів вищ. фрармац. навч. закл. / [О. А. Рубан, І. М. Перцев, С. А. Куценко та ін.]. - Харків : Золоті сторінки, 2016. - 720 с.

13. Математичне планування експерименту при проведенні наукових досліджень в фрармації / [Т. А. Грошовий, В. П. Марценюк, Л. І. Кучеренко та ін.]. - Тернопіль : Укрмедкнига, 2008. - 367 с.

Provizor. 2000; 14: 14-6. Russian.

4. Harnyk TP [Modern technologies of herbaldrug production and phytotherapy perspectives] Fititerapiia. Chasopys. 2008;1: 59-63. Ukrainian.

5. Vichkutkina EA. Creation of phytosbourg "Nefrolen" using a rational pharmacological approach. author's thesis. Perm. 2007. Russian.

6. Penzina TN. Pharmacological activity of some plants of

ISSN 2312-0967. Pharmaceutical review. 2018. № 2 
Фармацевтична технологія, біофармація, гомеопатія Pharmaceutical technology, biopharmacy, homeopathy

the Pyrolaceae family: author's thesis. Barnaul. 1999. Russian.

7. Mazepina LS. Ivanov AP, Fursa NS [The rationale for the use of Pyrola Rotundifolia traditional urological remedy] Vestnik Permskoy gosudarst. farmats. Akademii. 2010;7: 224-6. Russian.

8. Darzuli NP, Hroshovyi TA [Use of Pyrola Rotundifolia in medicine and pharmacy, prospects for the creation of new drugs] Fitoterapiia. 2015;3: 55-8. Ukrainian.

9. Bryukhanov VM, Zverev YaF, Sanarov EM. [Influence of the plants of the Pyrolaceae family on the function of the kidneys in the experiment] Farmatsiya. 1997;4: 41-2. Russian.

10. Darzuli NP, Denys Al, Hroshovyi TA [Marketing research of the market of drugs and dietary supplements used for treatment of inflammatory diseases of the urinary system]. Pharmaceutical review. 2017;4: 76-81.

11. State Pharmacopoeia of Ukraine. [Державна Фармакопея України: в 3 т.,2е вид.] Kharkiv: Derzhavne pidpryiemstvo "Naukovoekspertnyi farmakopeinyi tsentr"; 2015. Ukrainian.

12. Ruban OA, Pertsev IM, Kutsenko SA, Masliy YuS. Substances in the manufacture of drugs: teaching. manual for students of higher education [Допоміжні речовини у виробництві ліків: навч. посіб. для студентів вищ. фрармац. навч. закл.] Kharkiv: Zoloti storinku; 2016. Ukrainian.

13. Hroshovyi TA, Martsenyuk VP, Kucherenko LI, Vronska LV, Huryeyeva CM. Mathematical planning of experiment in pharmacy. [Математичне планування експерименту в орармації] Ternopil: Ternopil State Medical University; 2008. Ukrainian. 